UDK $630 * 2: 630 * 4 / .5(253)(497.6$ Grmeč $)$

\title{
DIVERZITET, STRUKTURA I TEKSTURA PRAŠUME I GOSPODARSKE ŠUME BUKVE I JELE SA SMRČOM NA GRMEČU U ZAPADNOJ BOSNI
}

\section{Diversity, structure and texture virgin and managed forest of beech and fir with spruce on Grmec Mountain in western Bosnia}

\author{
Sabahudin Solaković ${ }^{1}$
}

\begin{abstract}
The research of the diversity, structure and texture was performed on the mountain Grmeè in western Bosnia, in the summer and fall of 2007, in the virgin forest and in the managed forest of beech and fir with spruce. For the research purposes, a systematic network of experimental circles within the distance of 1 x $1 \mathrm{~km}$ was installed in the managed forest. On the intersection of the squares network, 14 circular surfaces of $25 \mathrm{~m}$ radius were installed. All circular surfaces were placed in different sections. In the virgin forest a permanent experimental surface of size $100 \times 100 \mathrm{~m}$ was set, with surface of 1 ha and one circular surface of radius $25 \mathrm{~m}$, with surface of $1963 \mathrm{~m} 2$. The research determined the horizontal (opposing) and vertical structure, the diversity, the quality of the resources and the health of the virgin forest plus the managed forest. The texture was determined only for the virgin forest. The diversity of the tree types over the number of trunks in the virgin forest is 1,79 , in the managed forest 1,78, over the basal; these indexes for the virgin forest are 1,24 and for the managed forest 1,64 . The virgin forest has a poorer structure of tree resources compared to the managed forest, but is of better health. In the managed forest there are many trunks of suspicious health, as much as $35,8 \%$. The texture diversity in the virgin forest is 2,43 .
\end{abstract}

Keywords: Virgin forest, managed forest, diversity, vertical structure, horizontal structure, texture, index of diversity, index of opposition

\section{Izvod}

Istraživanje diverziteta, strukture i teksure je obavljeno na planini Grmeč, $u$ zapadnoj Bosni, u ljeto i jesen 2007. godine, u prašumi i u gospodarskoj šumi bukve i

1 ŠGD Unsko-sanske šume, d.o.o. Bosanska Krupa 
jele sa smrčom. U cilju istraživanja u gospodarskoj šumi je postavljena sistematska mreža probnih krugova na rastojanju 1 x $1 \mathrm{~km}$. Na presjecištu mreže kvadrata postavljeno je 14 kružnih površina radijusa 25 metara. Sve kružne površine se nalaze u različitim odjelima. U prašumi je postavljena stalna ogledna ploha veličine 100 x 100 metara površine 1 ha $\mathrm{i}$ jedna kružna ploha radijusa $25 \mathrm{~m}$, površine $1963 \mathrm{~m} 2$. Istraživanjem je utvrđeno stanje horizontalne (konkurencija) i vertikalne strukture, zatim diverzitet, kvalitet zalihe i zdravstveno stanje prašume i gospodarske šume. Tekstura je utvrđena samo za prašumu. Diverzitet vrsta drveća preko broja stabala $u$ prašumi iznosi 1,79, a u gospodarskoj šumi 1,78. Preko temeljnice, ovi indeksi iznose za prašumu 1,24 i za gospodarsku šumu 1,64. Prašuma ima lošiju strukturu drvne zalihe u odnosu na gospodarsku šumu, ali zato ima bolje zdravstveno stanje. U gospodarskoj šumi ima dosta stabala sumnjivog zdravstvenog stanja, čak 35,8 \%. Teksturni diverzitet u prašumi iznosi 2,43.

Ključne riječi: prašuma, gospodarksa šuma, diverzitet, vertikalna struktura, horizontalna struktura, tekstura, indeksi diverziteta, indeksi konkurencije

\section{UVOD - Introduction}

U Bosni i Hercegovini se pod mješovitim šumama bukve i jele te bukve i jele sa smrčom nalazi 562.237 ha (MATIĆ I DRUGI, 1971). Ove šume predstavljaju privredno najznačajnije, društveno najkorisnije i ekološki najstabilnije šumske ekosisteme. Osim gospodarskih šuma koje se decenijama koriste za ljudske potrebe, unutar njih se nalaze i „netaknuti dijelovi šuma“ u kojima čovjek nije imao nikakvog ili pak malog, zanemarivog utjecaja na njihov nastanak, razvoj, dinamiku promjene i nestajanje. Takvi kompleksi šuma „netaknute prirode“ ili prašume izložene samo prirodnim utjecajima i promjenama, danas su svedene na manje i raštrkane grupe, različite površine, očuvanosti, pristupačnosti i različitog stepena zaštite. Pojam „prašume“ mnogobrojni istraživači su različito definirali; ČERMAK (1910), LEIBUNDGUT (1993), RUBNER (1960) i KORPEL (1996). Zajednička obilježja tih šuma su: prisustvo starih prezrelih stabala sa velikom zapreminom drveta, teško prohodnom podstojnom etažom, mnoštvom stojećeg i ležećeg mrtvog drveta i odsustvom čovjekovog djelovanja na njihov nastanak, razvoj, dinamiku promjena i nestanak.

Prašume su pogodne za istraživanje strukture, diverziteta i procesa koji se u njima odvijaju. Pored mjerenih taksacionih elemenata sastojine, broja stabala, temeljnica, zaliha, visina i drugih osobina, postoje i drugi parametri koji se mogu kvantitativno iskazati. Na ovaj način se mogu prikazati i odnosi koji postoje između pojedinih vrsta drveća, grmlja i prizemne flore unutar sastojine, posebno kada se govori o strukturi i konkurentskim odnosima među vrstama na određenoj površini. Konkurencija među vrstama se može izraziti preko indeksa koji definiraju te odnose. Ovi indeksi se oslanjaju prije svega na brojnost vrsta i prostorni raspored drveća, 
grmlja i prizemne vegetacije na određenoj površini u vertikalnom i horizontalnom pogledu.

Oni govore o konkurentskim odnosima i ostavljaju mogućnost pravovremenog reagiranja u pravcu optimiranja strukture unutar sastojine. Na ovaj način se izbjegava smanjenje i nestanak pojedinih vrsta drveća, povećava njihova stabilnost i proizvodne mogućnosti unutar fitocenoze.

\section{MATERIJAL I METODE ISTRAŽIVANJA - Material and methods}

\section{Područje istraživanja - Study area}

Istraživanje strukture, diverziteta $\mathrm{i}$ teksture je obavljeno $\mathrm{u}$ gospodarskoj jedinici „Grmeč-Palanka“ u zapadnoj Bosni, u šumama bukve i jele sa smrčom na krečnjačkoj podlozi unutar koje se nalazi i prašuma Bobija. Gospodarska jedinica „Grmeč- Palanka“ se nalazi u okviru šumsko-gospodarskog područja „Sansko“. Smještena je u jugozapadnom dijelu ovog područja. U visinskom dijapazonu se prostire od $391 \mathrm{~m}$ (Jelašinovačko polje) do $1.480 \mathrm{~m}$ (Javornjača). Ova gospodarska jedinica je u sebi objedinila sve karakteristične karstne fenomene, počev od polja, preko većih i manjih, blagih i dubokih vrtača, jama, pećina, jako izraženih blokova stijena (greda), grebena, kosa i vrhova. Uvjetovano mnogim faktorima, dominiraju različita zemljišta, a najčešće crnice i smeđa krečnjačka zemljišta, pojedinačno ili u mozaicima kalkomelanosol-kalkokambisol. Prema ekološko-vegetacijskoj podjeli ovo područje se nalazi u ključko-petrovačkom rejonu, zapadnobosanskog krečnjačkodolomitnog područja (STEFANOVIĆ I DR, 1983). Ovim šumama se gospodarilo i gospodari po principima potrajnog gospodarenja šumama, tako da su sačuvani veliki šumski kompleksi.

\section{Metodologija - Methodology}

Mjerenja su obavljena u prašumi na stalnoj oglednoj plohi i jednoj kružnoj površini, a u gospodarskoj šumi na sistematskom uzorku kružnih površina koje su postavljene u obliku mreže, na udaljenosti od 1 x $1 \mathrm{~km}$.

Primjerne kružne i kvadratne površine su na PC-u u programu WINGIS prvo postavljenje na rastere (topografske karte razmjere $1: 25.000$ ). Dobile su svoj redni broj, raspored u kojem odjelu se nalaze i pripadajuće geografske koordinate radi lakšeg identificiranja na terenu.

$\mathrm{Na}$ kružnim površinama su mjereni taksacioni elementi koji su bili potrebni za određivanje strukturnih i konkurentskih odnosa i diverziteta vrsta drveća.

U prašumi je položena jedna kružna površina radijusa 25 metara, a potom i stalna ogledna površina/ploha dimenzija stranica $100 \times 100$ metara, površine 1 ha. Stranice stalne ogledne plohe su orijentirane pravcem sjever - jug, istok - zapad. Prelomne tačke stalne ogledne plohe su snimljene GPS uređajem. 


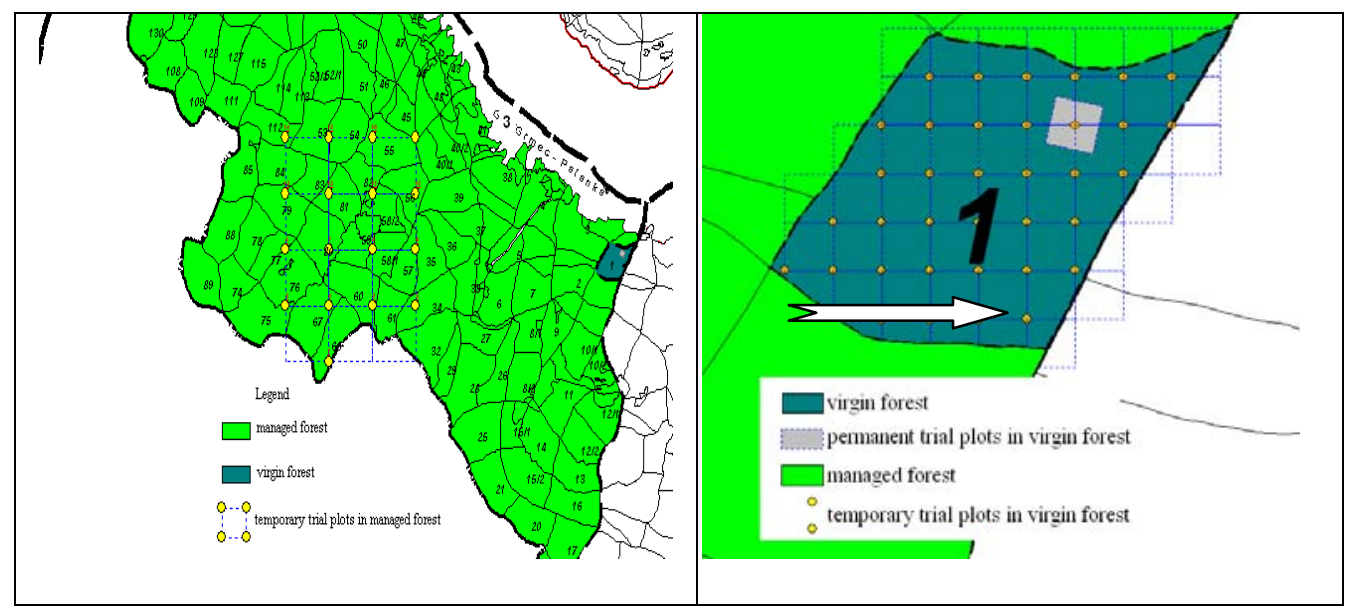

Slika 1. Položaj prašume, gospodarske šume bukve i jele sa smrčom i kružnih površina unutar GJ „Grmeč-Palanka“ i ŠGP „Sansko"

Figure 1. Location of the virgin and managed forest of beech, silver fir and spruce and circle plots into GJ "Grmeč-Palanka" and ŠGP "Sansko"

U gospodarskoj šumi je na terenu identifikovanim kružnim površinama, radijusa 25 metara, izvršen totalni premjer. U obzir su ušla sva živa dubeća stabla, čiji su prsni prečnici (na d1,30) bili veći od $5 \mathrm{~cm}$. Od centra kruga svakom je stablu, radi utvrđivanja indeksa konkurencije, određen položaj polarnom metodom, odnosno izmjerena udaljenost do na cm tačnosti.

Unutar istraživanog područja prašume, na jednom njenom dijelu, utvrđena je tekstrura prašume, tj. utvrđivano je prisustvo pojedinih razvojnih faza. $U$ deset linijskih pravaca, orijentisanih u pravcu sjevera, na međusobnom odstojanju od 12,5 metara, polagani su kvadrati, čije stranice iznose također 12,5 metara. Na svakom kvadratu je određena razvojna faza prašume. Ovu klasifikaciju je predložio meyer (1999) i primjenjuje se kod određivanja teksture prašume. Po ovoj metodici razlikuje se 7 razvojnih faza prašume i to: faza progale, faza podmlađivanja, optimalna faza, faza izjednačavanja, faza regeneracije, terminalna faza i faza raspadanja.

\section{REZULTATI ISTRAŽIVANJA - Results}

Struktura sastojine, odnosno raspored stabala i njihovo horizontalno miješanje kao i njihove konkurentske odnose u borbi za prostor i vertikalno raslojavanje na određenoj površini može se prikazati preko horizontalne strukture, odnosno rasporeda stabala na određenoj površini, tj. njihova međusobna udaljenost, miješanje vrsta i uticaj jednih na druge. Drugi način prikazivanja strukture sastojine je preko njene visinske strukture, odnosno rasporeda visina i njihove izmiješanosti, gdje su prikazani 
slojevi/spratovi sastojine, urastanje krošnji jednih u druge, njihov visinski raspored i distribucija.

\section{Horizontalna struktura i konkurencija - Horizontal structure and competition}

Postoji više indeksa pomoću kojih se može izraziti horizontalna struktura sastojine. Jedan od indeksa koji se najčešće koristi u analiziranju i gdje nam kao polazište služi raspored stabala na probnim površinama je indeks po ClarK and Evans (1954).

Za izračunavanje ovoga indeksa na svakoj plohi je odabrano po 38 stabala koji su bili najbliži centru kruga. Broj od 38 stabala je uzet iz razloga što je na primjernoj površini, koja je položena u prašumi na krugu radijusa 25 metara, evidentirano 39 stabala. Površina plohe za ovaj indeks je obračunata tako da je udaljenost najdaljeg stabla, od 38 stabala koji su najbliži centru kruga, poslužila kao radijus kruga na osnovu kojega je izračunata površina. Zbog toga površine na plohama, za računanje ovog indeksa, imaju različite veličine. Kod ovog indeksa nije preporučeno uzeti manje od 30 stabala za izračunavanje.

Tabela 1. Indeks po CLARK \& EVANSU za gospodarsku šumu i prašumu Table 1 CLARK \& EVANS index of menaged forest and virgin forest

\begin{tabular}{|c|c|c|c|}
\hline Tipe of forest & $\begin{array}{c}(\bar{r}) \text { prosječna } \\
\text { distanca }\end{array}$ & $\begin{array}{c}\mathrm{E}(\bar{r}) \text { - očekivana } \\
\text { vrijednost. }\end{array}$ & $\begin{array}{c}\text { Clark \& Evans } \\
\text { indeks }\end{array}$ \\
\hline Managed forest & 1,67 & 1,64 & 1,01 \\
\hline Virgin forest & 5,10 & 3,66 & 1,39 \\
\hline
\end{tabular}

Prosječni indeks za gospodarsku šumu iznosi 1,01. Prema tome, prostorna raspodjela stabala unutar gospodarske šume ima uglavnom slučajni raspored, međutim tendencija je grupiranja stabala, odnosno formiranja skupinaste strukture.

U prašumi vrijednost indeksa je 1,39. Ona ukazuje da priroda, nedirana od strane čovjeka, ima izražen slučajni raspored stabala.

\section{Konkurencija - Competition}

$\mathrm{Za}$ obračun konkurencije među stablima korišten je indeks konkurencije po HEGYIU. Vrijednosti HEGYI indeksa oko nule govore da je prsni prečnik centralnog stabla dosta veći od posmatranih susjednih stabala. Što je veće rastojanje između stabala utoliko je konkurencija manja. Obrnuto, konkurencija je veća ukoliko su susjedna stabla deblja i raspoređena su bliže do centralnog stabla. U narednoj tabeli predstavljen je izračunati HEGYI indeks za gospodarsku šumu i prašumu. 
Tabela 2. HEGYI indeks za gospodarsku šumu i prašumu

Table 2 HEGYI index of menaged forest and virgin forest

\begin{tabular}{|l|c|c|}
\hline Kat. šume & Prečnik centralnog stabala d1,30 cm & Hegyi indeks \\
\hline menaged forest & 19,4 & 3,27 \\
\hline virgin forest & 13,0 & 4,18 \\
\hline
\end{tabular}

\section{Visinska struktura - Height structure}

U tabeli 3 preko gornje visine sastojine prikazana je visinska struktura stabala u gospodarskoj šumi i prašumi.

Tabela 3. Visinska struktura stabala u sastojini za gospodarsku šumu i prašumu

Table 3 The height structure of trees in a stand for menaged forest and virgin forest

\begin{tabular}{|r|r|r|r|r|r|c|c|}
\hline \multirow{2}{*}{ Prosjek } & \multirow{2}{*}{$\begin{array}{c}\text { Gornja } \\
\text { visina } \\
\text { sastojine }\end{array}$} & \multicolumn{4}{|c|}{ Struktura visina sastojine po IUFRO - klasifikaciji } \\
\cline { 3 - 8 } & & $\begin{array}{c}\text { N stabala po } \\
\text { ha }\end{array}$ & $\%$ & $\begin{array}{c}\text { N stabala po } \\
\text { ha }\end{array}$ & $\%$ & $\begin{array}{c}\text { N stabala } \\
\text { po ha }\end{array}$ & $\%$ \\
\hline Gosp.šuma & 26,07 & 314 & 32 & 353 & 35 & 334 & 33 \\
\hline Prašuma & 34,60 & 139 & 32 & 82 & 18 & 218 & 50 \\
\hline
\end{tabular}

Posmatrajući gospodarsku prebornu šumu i prašumu uočljivo je da je gornja visina sastojine prašume znatno veća nego kod gospodarske šume. Također, vidi se da je struktura broja stabala gospodarske šume, raspoređenih po IUFRO - klasama, približno jednako zastupljena u svakoj klasi. U prašumi je situacija drugačija. Najmanje ima stabala sa visinama od $1 / 3$ do $2 / 3$ gornje visine sastojine, a polovina stabala ima visine koje se nalaze u visinskoj klasi manje od 1/3 gornje visine sastojine. U klasi više od $2 / 3$ gornje visine sastojine i gospodarska šuma i prašuma imaju isto učešće broja stabala.

\section{Diverzitet - Diversity}

Najjednostavnija i najstarija mjera diverziteta je broj vrsta u zajednici. Osim broja vrsta i njihove brojnosti i zastupljenosti u nekoj zajednici, za izračunavanje Shannon-Wiener $(\mathrm{H})$ indeksa heterogenosti i izjednačenosti E (Evanness) se mogu koristiti temeljnice stabala $\mathrm{G}(\mathrm{m} 2 / \mathrm{ha})$ ili drvna zaliha stabala V (m3/ha) neke sastojine, odnosno biljne zajednice. U narednoj tabeli su predstavljeni Shannon-Wiener $(\mathrm{H})$ indeks heterogenosti i izjednačenosti E (Evanness) za gospodarsku šumu i za prašumu preko broja stabala sastojine i temeljnice stabala sastojine. 
Tabela 4. Indeks heterogenosti i izjednačenost po broju vrsta i temeljnici za gospodarsku šumu i prašumu

Table 4. The index of heterogeneity and a tie in the number of species and basal area of menaged and virgin forest

\begin{tabular}{|c|c|c|c|c|c|c|c|}
\hline \multirow{3}{*}{ Plohe } & \multicolumn{4}{|c|}{ Indeksi po broju stabala $(\mathrm{N})$} & \multicolumn{3}{|c|}{ Indeksi po temeljnici $(\mathrm{G})$} \\
\hline & \multicolumn{2}{|r|}{ Broj } & \multirow{2}{*}{$\begin{array}{l}\text { Shannon } \\
\text { Wiener H }\end{array}$} & \multirow{2}{*}{ Evannes E } & \multirow{2}{*}{$\begin{array}{c}\text { Temeljnica } \\
\mathrm{m}^{2} / \mathrm{ha}\end{array}$} & \multirow{2}{*}{$\begin{array}{c}\text { Shannon } \\
\text { Wiener H }\end{array}$} & \multirow{2}{*}{ Evannes E } \\
\hline & vrsta & indivudua & & & & & \\
\hline Gosp.šuma & 8 & 1.001 & 1,78 & 0,35 & 40,71 & 1,65 & 0,34 \\
\hline Prašuma & 7 & 439 & 1,79 & 0,40 & 45,28 & 1,24 & 0,24 \\
\hline
\end{tabular}

Posmatrajući gospodarsku šumu i prašumu te upoređujući njihove indekse, obračunate preko broja stabala, vidi se da gospodarska šuma i prašuma imaju skoro iste Shannon-Wiener $(\mathrm{H})$ indeks heterogenosti. Prašuma ima samo neznatnu veću izjednačenost E (Evanness) od gospodarske šume. Kada se ovi indeksi izračunavaju preko temeljnice stabala sastojine, onda je evidentno da je situacija drugačija. Gospodarska šuma ima veći Shannon-Wiener $(\mathrm{H})$ indeks heterogenosti i on iznosi 1,65. I izjednačenost E (Evanness) je također veća u gospodarskoj šumi i iznosi 0,34.

\section{Razvojne faze prašume - Developmental stages of the rainforest}

Razvojne faze prašume i teksturni diverzitet su utvrđivani samo za prašumski odjel. Sve plohe u gospodarskoj šumi su uglavnom imale prebornu strukturu koja odgovara fazi izjednačavanja, tako da nije bilo moguće utvrđivanje teksturnog diveziteta. U gospodarskoj šumi je izražen antropogeni utjecaj, tj. sistem gospodarenja određuje više - manje i strukturu, odnosno razvojne faze sastojine. Stoga u gospodarskoj šumi nema smisla određivati razvojne faze i teksturni diverzitet. Pod teksturom podrazumijevamo prostorni raspored pojedinih razvojnih faza prašume u nekom trenutku. Razvojna faza je dio prašume koji se površinski i strukturno jasno razlikuje od susjednih prašumskih dijelova. Prašuma je mozaično podijeljenja na razvojne faze koje se isprepliću i nižu. Površina na kojoj se prostire pojedina razvojna faza, njezin oblik te povezanost sa ostalim razvojnim fazama govore o životu prašume i utjecajima kojima je bila izložena, npr. vjetar, požar, kalamiteti. Na osnovu zastupljenosti pojedinih razvojnih faza, može se zaključiti koja faza prašume dominira u njenom razvoju. Sljedeća tabela prikazuje razvojne faze u prašumi i frekvenciju pojavljivanja pojedinih razvojnih faza.

Tabela 5. Frekvencija pojavljivanja pojedinih razvojnih faza u prašumi

Table 5 Frequency of occurrence of certain developmental stages in the virgin forest

\begin{tabular}{|l|c|}
\hline Razvojne faze unutar prašume & Frekvencija pojavljivanja \\
\hline Progale & 7 \\
\hline Podmlađivanje & 8 \\
\hline Optimalna faza & 12 \\
\hline Izjednačavanje (preborna faza po LEIBUNGUTU) & 28 \\
\hline Regeneracija & 11 \\
\hline Terminalna faza & 32 \\
\hline Raspadanje & 2 \\
\hline
\end{tabular}


Posmatrajući zastupljenost pojedinih razvojnih faza koje su evidentirane u prašumi, vidi se da je najzastupljenija terminalna faza. Ona se javlja na $32 \%$ površine mjerenog dijela prašume. Za ovu fazu su karakteristična krupna, vrlo visoka stabla sa velikim visinama, iz čega rezultira i veliki udio ovih debelih stabala u zapremini sastojine. Sljedeća najbrojnija faza je faza izjednačavanja (po LEIBUNGUTU preborna faza), koja je zastupljena na $28 \%$ površine. Ove dvije faze zauzimaju $60 \%$ površine prašume. Na optimalnu fazu otpada $12 \%$ površine, a na fazu regeneracije 11 \% površine. Faza progale je zastupljena sa $8 \%$, a faza podmlađivanja sa $7 \%$. Najmanje je zastupljena faza raspadanja, sa samo $2 \%$ površine prašume.

Prostorni raspored pojedinih razvojnih faza je prikazan na sljedećoj šemi.

\begin{tabular}{|l|l|l|l|l|l|l|l|l|l|}
\hline 2 & 2 & 2 & 2 & 3 & 3 & 4 & 6 & 6 & 3 \\
\hline 6 & 2 & 5 & 6 & 3 & 1 & 4 & 6 & 4 & 4 \\
\hline 6 & 5 & 5 & 6 & 3 & 3 & 6 & 6 & 5 & 4 \\
\hline 6 & 3 & 5 & 5 & 3 & 6 & 6 & 6 & 5 & 6 \\
\hline 4 & 4 & 5 & 5 & 6 & 6 & 6 & 6 & 5 & 1 \\
\hline 6 & 6 & 1 & 6 & 6 & 6 & 7 & 4 & 5 & 1 \\
\hline 3 & 6 & 4 & 6 & 1 & 4 & 4 & 4 & 7 & 3 \\
\hline 1 & 4 & 6 & 4 & 6 & 4 & 1 & 6 & 6 & 4 \\
\hline 3 & 3 & 4 & 4 & 6 & 4 & 4 & 2 & 4 & 4 \\
\hline 4 & 4 & 4 & 6 & 2 & 4 & 6 & 2 & 4 & 4 \\
\hline
\end{tabular}

Šema 1. Prostorni raspored razvojnih faza prašume

Sheme 1. Spatial distribution of developmental stages of rainforest

Legenda:

\begin{tabular}{|l|c|}
\hline Razvojna faza & $\begin{array}{l}\text { Šema } \\
\text { boja }\end{array}$ \\
\hline Progale & 1 \\
\hline Podmlađivanja & 2 \\
\hline Optimalna faza & 3 \\
\hline Izjednačavanja (preborna) faza & 4 \\
\hline Regeneracije & 5 \\
\hline Terminalna faza & 6 \\
\hline Raspadanja & 7 \\
\hline
\end{tabular}

$\mathrm{Na}$ osnovu prisustva pojedinih razvojnih faza i njihovog procentualnog udjela na istraživanoj površini izračunat je teksturni diverzitet, analogno vrsnom diverzitetu, 
pomoću Shannon-Wiener (H) indeksa heterogenosti (SHANNON \& WEAVER, 1976) i Evanness E izjednačenosti (PIELou, 1966). Kao pokazatelj raznovrsnosti ovdje se ne koristi, kako je uobičajeno, pripadnost vrsti, nego prisustvo pojedinih razvojnih faza u odnosu na površinu koju zauzimaju. Istraživanjem teksturnog diverziteta bavili su se TABAKU (1999) i VIŠNJIĆ I DR. (2009). Teksturni diverzitet prašumskog odjela na Grmeču je prikazan u tabeli broj 6 .

Tabela 6. Teksturni diverzitet unutar istraživanog prašumskog odjela Table 6. The textural diversity within the virgin forest

\begin{tabular}{|l|c|l|}
\hline & $\begin{array}{l}\text { Shannon-Wiener H indeks } \\
\text { heterogenosti }\end{array}$ & $\begin{array}{l}\text { Evanness } \\
\text { izjednačenost }\end{array}$ \\
\hline Teksturni diverzitet & 2,43 & 0,65 \\
\hline
\end{tabular}

Vrijednost Shannon-Wiener $(\mathrm{H})$ indeksa heterogenosti od 2,43 pokazuje da se radi o veoma izraženom teksturnom diverzitetu. On se nalazi iznad vrijednosti koje su dobijene za pojedine prašumske rezervate u Njemačkoj i Albaniji (TABAKU, 1999). Indeks 2,43 je nešto niži, ali je vrlo blizu indeksa, koji su VIŠNJIĆ I DR. (2009) utvrdili u prašumi na Plješevici. Izjednačenosti E (Evanness) ima srednju vrijednost, jer sve razvojne faze nisu podjednako zastupljene. Dvije razvojne faze, terminalna faza i faza izjednačavanja (po leibundgutu preborna faza) zauzimaju $60 \%$ površine prašume.

\section{DISKUSIJA - Discusion}

Utvrđivana je horizontalna struktura sastojine, odnosno prostorni raspored stabala. U tu svrhu, prilikom mjerenja na plohama, za svako stablo je izmjeren azimut i udaljenost od centra kruga. Za izračunavanje horizontalne strukture sastojine korišten je indeks po CLARK \& EVANSU, a za izračunavanje konkurencije između drveća korišten je HEGYI indeks konkurencije. Premjerom je obuhvaćeno onoliko stabala koliko ih je bilo na oglednoj plohi radijusa 25 metara, koja je položena u prašumi. Za stabla koja su obuhvaćena premjerom, izračunata je površina na kojoj se nalaze i prosječna udaljenost na bazi odstojanja između dva najbliža susjedna stabala. Izračunati prosječni indeks po CLARK \& EVANSU u gospodarskoj šumi iznosi 1,01 a u prašumi 1,39. Kako je kazano, vrijednosti CLARK \& EVANS indeksa ispod 1 ukazuju na tendenciju grupiranja stabala, odnosno formiranja skupinaste strukture, a vrijednost indeksa preko 1 ukazuju na tendenciju slučajnog (stablimičnog) rasporeda stabala u prostoru. Istaživanjem je utvrđeno da u prašumi stabla imaju tendenciju izrazito naglašenog slučajnog (stablimičnog) rasporeda u prostoru.

HEGYI indeks se koristi za utvrđivanje konkurencije između stabala na površini. Za izračunavanje ovog indeksa se uzima centralno stablo (najčešće stablo najbliže centru kruga) i njemu najbližih 5 stabala. U gospodarskoj šumi prosječni HEGYI indeks je iznosio 3,27 a u prašumi 4,18. Vrijednost HEGYI indeksa oko 0 
govori da je prsni prečnik centralnog stabla dosta veći od okolnih susjednih stabala. Što je veće rastojanje između stabala, konkurencija je manja. Što su pak susjedna stabla deblja i udaljenost je manja, konkurencija je veća. U prašumi su veće prosječne udaljenosti između susjednih stabala, pa je konkurencija manje izražena nego u gospodarskoj šumi.

U gospodarskoj šumi, utvrđena je prosječna gornja visina sastojine u iznosu od 26,07 metara. Raspoređujući stabla po IUFRO - klasifikaciji u tri visinske klase, dobijamo u svim klasama približno podjednaku zastupljenost stabala. Na osnovu ovoga možemo konstatirati da je sklop gospodarske šume, ako se posmatra kroz visinski presjek sastojine, u potpunosti ispunjen krošnjama stabala, odnosno ima tipičan verikalan sklop. Ovakav sklop je karaktrističan za preborne sastojine. Posmatrajući visinsku strukturu stabala u prašumi i utvrđujući gornju visinu sastojine po IUFRO - klasifikaciji, utvrđena je gornja visina stabala prašume koja iznosi 34,60 metara. Zastupljenost stabala po klasama je $32: 18: 50$. Ovakva sastojina je sastavljena iz dva odvojena sklopa, odnosno ima uglavnom karakteristike dvoetažne sastojine. Pridoda li se ovome i činjenica da je utvrđivanjem razvojnih faza, o čemu će biti riječi kasnije, utvrđeno prisustvo tipične preborne faze na samo $28 \%$ površine prašume, onda imamo potpunu sliku prašume kao pretežno dvoetažne sastojine.

„Prirodni uslovi mogu dati maksimalnu količinu drvne mase, ali ne i najvrijednije. Kvalitet će ovisit od čitavog niza faktora, a jedan od njih je i njega šume“" (PINTARIĆ, 1991).

Od kvaliteta drvne zalihe i njene raspodjele po debljinskim klasama zavisi i kvalitet sječive drvne mase, a time i asortiman proizvoda koji se mogu dobiti iz tih masa. Od svega ovoga na kraju zavisi i finansijski efekt preduzeća. U radu je utvrđivan kvalitet drvnih masa po uzgojno-tehničkim i tehničkim kvalitetnim klasama. Također je i prema IUFRO - klasifikaciji utvrđivano zdravstveno stanje gospodarske šume i prašume.

Kod utvrđivanja indeksa vrsta drveća, Shannon-Wiener (H) indeks heterogenosti i izjednačenost E (Evanness) su preračunavani preko vrste drveća i preko temeljnice.

Kada se preračunava preko broja stabala Shannon-Wiener $(\mathrm{H})$ indeks heterogenosti u gospodarskoj šumi iznosi 1,78 a izjednačenost $\mathrm{E}$ (Evanness) 0,35. U prašumi Shannon-Wiener $(\mathrm{H})$ indeks heterogenosti iznosi 1,79 a izjednačenost $\mathrm{E}$ (Evannes) 0,40. Kada se posmatraju mjere heterogenosti i izjednačenosti preko temeljnice, onda prašuma ima dosta niže vrijednosti Shannon-Wiener $(H)$ indeksa heterogenosti koji iznosi 1,24 a u gospodarskoj šumi 1,65. Izjednačenost E (Evanness) je također manja u prašumi i iznosi 0,24 , a u gospodarskoj šumi 0,34 .

Samo u prašumi istraživana je tekstura, odnosno prostorni raspored pojedinih razvojnih faza prašume $u$ nekom trenutku. Pod razvojnom fazom podrazumijevamo dio prašume koji se površinski i strukturno jasno razlikuje od susjednih prašumskih dijelova. Istraživanjem je utvrđeno da najveću površinu zauzima terminalna faza sa 32 \%. Za njom slijedi preborna faza sa $28 \%$. Ove dvije faze ukupno čine $60 \%$ površine 
prašume. Ostalih $40 \%$ otpada na ostalih pet faza i to: optimalnu fazu $12 \%$, fazu regeneracije $11 \%$, fazu podmlađivanja $8 \%$, fazu progale $7 \%$ i fazu raspadanja $2 \%$.

VIŠNJIĆ I OSTALI (2009) u istaživanjima prašume na Plješevici utvrdili su da dominira faza raspadanja sa $24 \%$, a za njom slijede preborna faza i optimalna faza sa po $20 \%$. ANIĆ I MIKAC (2008) su u prašumi Čorkova uvala istraživanjima teksture prašume došli do rezultata da terminalna faza dominira sa $65 \%$, optimalna sa $18 \%$, a na tipičnu prebornu fazu otpada samo $8 \%$ površine prašume.

I KOPREL (1996) je u svojim istraživanjima prašuma Slovačke došao do saznanja da tipična preborna faza u strukturi prašume zauzima manje od jedne trećine razvojnog ciklusa prašume. ANIĆ I MIKAC (2008) prenose MEYERA (1976) koji je utvrdio da preborna faza u prašumama bukve i jele sa smrčom nastaje na malim površinama $i$ da je ona samo prelazni razvojni stadij, jer stabla uvijek nastoje nivelirati sklop. Nasuprot ovom mišljenju KRAMARIĆ I INCULANO (1989) su zaključili kako je struktura cijele prašume preborna i strogo stablimičnog rasporeda stabla, a pojedine razvojne faze prostiru se na malim površinama, koje u potpunosti stvaraju preborni oblik sklopa.

U tipično prebornoj fazi dolazi do stvaranja vertikalnog sklopa, stabla su raspoređena $\mathrm{u}$ svim slojevima $\mathrm{i}$ kontinuirano se odvijaju pozitivna visinska pomjeranja.

U prašumi su izračunate vrijednosti Shannon-Wiener $(H)$ indeksa heterogenosti i izjednačenosti E (Evanness), odnosno određen teksturni diverzitet. Vrijednost Shannon-Wiener $\mathrm{H}$ indeksa heterogenosti je dosta veća nego $u$ istraživanjima TABAKU (1999), koji je u prašumi Heilige Hallen u Njemačkoj utvrdio Shannon-Wiener $(\mathrm{H})$ indeks heterogenosti od 1,81. U prašumama Albanije isti autor je utvrdio kod određivanja teksturnog diverziteta sljedeće vrijednosti Shannon-Wiener (H) indeksa heterogenosti: u prašumama Puka i Raica indeks od 1,49 a u prašumi Mirdita indeks od 1,47. VIŠNJIĆ I OSTALI (2009) su u prašumi na Plješevici utvrdili Shannon-Wiener $(\mathrm{H})$ indeks heterogenosti od 2,45 koji je nešto veći od vrijednosti utvrđene za ovu prašumu. Ova prašuma, kao i prašuma na Plješevici, ima vrlo veliki Shannon-Wiener $(\mathrm{H})$ indeks heterogenosti. On mnogo veći od istih u prašumama Njemačke i Albanije.

Izjednačenost E (Evanness) u istraživanoj prašumi iznosi 0,65. Vrijednost ovog indeksa je manja od istraživanja TABAKU (1999) u prašumama Njemačke i Albanije i vrijednosti koje su VIŠNJIĆ I OSTALI (2009) utvrdili u prašumi na Plješevici. Prašuma Heilige Halle u Njemačkoj ima vrlo visoku izjednačenost E (Evanness) koja iznosi 0,93. U prašumama Albanije, utvrđene su sljedeće vrijednosti: Puka ima izjednačenost E (Evanness) od 0,80, prašuma Raica od 0,72, a prašuma Mirdita 0,75. Prašuma Plješevica ima izjednačenost E (Evanness) od 0,81. Istraživana prašuma na Grmeču ima manju izjednačenost od naprijed navedenih prašuma. Razvojne faze nisu podjednako zastupljene na površini prašume jer dominiraju dvije sa $60 \%$ učešćem. To su faza izjednačavanja i terminalna faza. Na preostalih pet faza otpada $40 \%$ površine. Najveća vrijednost izjednačenosti E (Evanness) bi bila u slučaju da su sve razvojne faze podjednako zastupljene. 


\section{ZAKLJUČCI - Conclusion}

$\mathrm{Na}$ osnovu provedenih istraživanja i analize dobivenih rezultata može se zaključiti sljedeće:

CLARK \& EVANS kvantificiraju horizontalnu strukturu sastojine i šemu rasporeda stabala u prostoru. Vrijednost ovog indeksa u prašumi opisuje karakter horizontalne strukture prašume koja ima tendenciju pretežno slučajnog (stablimičnog) rasporeda stabala. U gospodarskoj šumi indeks pokazuje da horizontalna struktura sastojine ima uglavnom tendenciju grupiranja stabala, odnosno skupinastu strukturu stabala. U gospodarskoj šumi odabrani sistem gospodarenja je skupinasto-preborni, koji ima tendenciju formiranja skupina različitih vrsta drveća i različite starosti. Ovo pokazuje kako gospodarski zahvati utječu na formiranje skupina, što je i predviđeno sistemom gospodarenja. Indeks po CLARK \& EVANSU u gospodarskoj šumi iznosi 1,01 , a u prašumi 1,39 .

HEGYI indeks obilježava konkurenciju između stabala na određenoj površini. U gospodarskoj šumi stabla su u prosjeku bliža centralnom stablu, konkurencija između stabala je veća i izraženija, što pokazuje i vrijednost indeksa koji iznosi 3,27. U prašumi je konkurencija između stabala manja, jer su stabla više udaljena od centralnog stabla i indeks ima veće vrijednosti i iznosi 4,18.

Gornja visina stabala gospodarske šume iznosi $26,07 \mathrm{~m}$, a u prašumi iznosi $34,60 \mathrm{~m}$ i za 8,53 metra je veća od gornje visine gospodarske šume. Stabla su po visinama grupirana u tri skupine po IUFRO - klasifikaciji. Raspored stabala po IUFRO - klasifikaciji u gospodarskoj šumi i u prašumi je posve različit i pokazuju tendenciju formiranja posve različitih oblika sklopa sastojine. U gospodarskoj šumi, stabla su podjednako zastupljena u sve tri etaže, sa po $1 / 3$ ukupnog broja stabala. U prašumi dominiraju stabla donje etaže i to sa $50 \%$ i stabla gornje etaže sastojine sa $32 \%$, što pretpostavlja pretežno dvoslojni sklop. Zaključak je da treba i dalje nastaviti održavati ovakav raspored stabala po visinama u gospodarskoj šumi, koji i jeste karakteristika prebornih šuma bukve i jele sa smrčom.

Po učešću vrsta drveća, prašuma i gospodarska šuma imaju približno iste indekse, ali po učešću temeljnice, gospodarska šuma ima daleko veće vrijednosti ovih indeksa. Razlog leži u činjenici da u prašumi bukva znatno dominira kako u ukupnoj temeljnici, tako i u drvnoj zalihi. Njeno učešće u broju stabala je približno jednako učešću npr. jele. U gospodarskoj šumi je diverzitet po temeljnici veći što ukazuje na pravilno optimiranje udjela glavnih vrsta drveća prilikom provođenja gospodarskih zahvata.

Prašuma ima mozaično zastupljene pojedine razvojne faze na određenoj površini. Najveću površinu ima terminalna faza a najmanju faza raspadanja. $\mathrm{Na}$ tipičnu prebornu fazu otpada manje od $1 / 3$ površine. Zbog mozaičkog rasporeda različitih razvojnih faza u površini sastojine, čitava površina prašume ima izgled preborne šume stablimičnog rasporeda stabla, a pojedine razvojne faze prostiru se na malim površinama koje u potpunosti stvaraju preborni oblik sklopa. 
Teksturni diverzitet prašume je dosta veliki i karakterističan je za prirodne šume mješovite strukture kakve su šume bukve i jele sa smrčom. Na veliki indeks teksturnog diverziteta pored strukture i sastava ovih šuma utječu i orografsko - edafske karakteristike koje su u području istraživanja jako izražene. Shannon-Wiener $(\mathrm{H})$ indeks heterogenosti je dosta veliki i ima skoro istu vrijednost kao i prašuma na Plješevici. Evanness E izjednačenosti je nešto niži, a razlog leži u činjenici da dvije razvojne faze dominiraju površinom sa $60 \%$.

\section{LITERATURA - References}

ANIĆ, I., MIKAC, S. 2008: Struktura, tekstura i podmlađivanje Dinarske bukovo-jelove prašume Čorkova Uvala, Šumarski list br. 11-12, CXXXII, Zagreb, str 505-515.

Leibundgut, H., 1993: Europäische Urwälder. Verlag Paul Haupt, Bern, Stuttgart

KOPREL, Š., 1996: Razvoj i struktura bukovo-jelovih prašuma i njihova primjena kod gospodarenja prebornom šumom, Šumarski list br. 3-4, CXX, str 303-308.

KRAMARIĆ, Ž., IUCULANO, T., 1989: O strukturi i normalitetu šume bukve i jele (AbietiFagetum illyricum /Horv. 1938/) na primjeru prašume Čorkova uvala, Šumarski list CXIII; Zagreb, 581-589.

Matić. V., DRINIĆ. P., Stefanović. V., ĆIRIĆ. M.. i saradnici, 1971: Stanje šuma u SR Bosni i Hercegovini prema inventuri šuma na velikim površinama u 1964 1968. godini, Šumarski fakultet i Institut za šumarstvo u Sarajevu, Posebna izdanja broj 7, Sarajevo, 1-639.

MeYER, P., 1999: Bestimmung der Waldentwicklungsphasen und der Texturdiversität in Naturwäldern, Allg.Forst-u. J.-Ztg., 170. Jg. 10-11, 203-211.

Pielou, E. C., 1966: The measurement of diversity in different types of biological collections. J. theor. Biol. 10, 134-144.

PINTARIĆ, K., 1991: Uzgajanje šuma - Tehnika obnove i njege sastojina, Šumarski fakultet u Sarajevu, 1-246.

ShanNON, C. E. AND WeAVer, W., 1976: Mathematische Grundlagen der Informationstheorie. Muenchen, Wien, Oldenburg, 1976

TABAKU, V., 1999: Struktur von Buchen-Urwäldern in Albanien im Vergleich mit deutschen Buchen-Naturwaldreservaten und - Wirtschaftswäldern. Dissertation, Cuvillier Verlag Goettingen.

VIŠNJIĆ, Ć., VoJNIKOVIĆ, S., IORAS, F., DAUTBAŠIĆ, M., ABRUDAN, I.,V., GUREAN, D., LOJO, A., TReŠtić, T., Ballian, D., BajRIĆ, M., 2009: Virgin Status Assessment of Plješevica in Bosnia-Herzegovina, Notulae Botanicae Horti Agrobotanici Cluj 37 (2), 22-27. 


\section{SUMMARY}

A surface of 562237 ha in Bosnia and Herzegovina is under the mixed forests of beech and fir, and beech, fit and spruce forests. These forests are economically the most important, socially useful and ecologically stable forest ecosystems. This paper caontains a comparative analysis of structure, texture and diversity of the managed forests of beech and fir with spruce and of the virgin forest.The research of the diversity, structure and texture is performed on the mountain Grmeč in western Bosnia, in the summer and fall of 2007 in the virgin forest and in the managed forest of beech and spruce-fir.

In the managed forest, the selected management system is group-seeded and has the tendency of forming groups of different tree types and different age. This shows how the economic steps affect the forming of groups that is anticipated with the management system.

The layout of the trunks according to IUFRO - classification in the managed forest and in the virgin forest is totally different and shows the tendency of forming of different shapes of curtain composition. In the managed forest, the trunks are equally represented in all three stages, with $1 / 3$ of the whole trunk number. In the virgin forest, trunks of lower stage dominate with $50 \%$ and trunks of higher stage composition with $32 \%$, that represents mostly a double-layered curtain. It needs to be continued to maintain such a layout of trunks per heights in the managed forest and that is a characteristic of seeded beech forests and spruce-fir.

Regarding the participation of trunks from virgin forests and managed forests, they have approximately the same indexes and regarding the basal, the managed forest has far higher values of those indexes.

The virgin forest has a mosaic-like development phases on the specific surface. The biggest surface has the terminal phase and the smallest has the phase of decomposition.

The texture diversity of the virgin forest is vast and is characteristic for natural forests of mixed structure like beech forests and spruce-fir. On the big index of the texture diversity, beside the structure and composition of this forests, the geographical characteristics also have influence, that is very distinctive in the field of research. 